\title{
Cooperation and conflicts among Latin American religions
}

\author{
Frank Usarski ${ }^{1}$
}

Published online: 21 November 2017

(C) Springer International Publishing AG, part of Springer Nature 2017

Inspired by the growing interest in our still young journal, we are handing the second issue of the International Journal of Latin American Religions over to our readers. The main body of the current edition is composed of twelve articles of which ten have been selected for the thematic section. The latter is dedicated to reflections on cases and modes either of cooperation or of tensions between groups or individuals relevant for the study of religious phenomena located in or related to Latin American countries. Some of the articles of this category are expanded versions of papers presented at the conference of the International Society for the Sociology of Religions (July 4th-7th in Lausanne, Switzerland) on "Religion, Cooperation and Conflict in Diverse Societies" including the more specific panel on "Cooperation and Conflicts among Latin American Religions". Other contributions came from experts who have approached the topic in the context of major publications on certain segments of the field of Latin American Religions.

The common denominator of the thematic papers is the recognition of the increasing religious diversity of the religious fields of Latin American countries and the detrimental effects of this plurality for Catholicism as the traditionally dominant religious tradition in the region. In addition, the majority of the authors call attention to the importance of Pentecostalism as the statistically strongest and, in terms of the future, most auspicious competitor.

Over this overall background and supported by empirical data which prove the growing differentiation of the Mexican religious landscape and potential conflicts due to this constellation, Renée de la Torre, Alberto Hernández, and Cristina Gutiérrez Zúñiga problematize a hasty application of the secularization theory to Mexico.

Focusing on Brazilian Pentecostalism, Joanildo Burity stresses the complementarity between the institutional upsurge of evangelical Pentecostal churches and the social reinforcement of its political representatives. The latter is instrumental for a successful

Frank Usarski

usarski@pucsp.br

1 Pontifical Catholic University of São Paulo, São Paulo, SP, Brazil 
engagement in the political field, which, in turn, creates new forms of conflict in the public sphere by putting in question the common sense of traditionally established rules based on the principle of separation between State and Religion.

Roberto Motta also stresses the shortcomings of the secularization theory and the growing theoretical and political importance of Pentecostalism. In addition, he reminds his readers of the perseverance of Afro-Brazilian Religions, and the inclination of many Brazilians to religious laissez-faire and syncretism.

André Ricardo de Souza contributes to these reflections by shedding light on "ecumenical" tendencies among approaching Brazilian Catholics, Protestants, and Spiritists thus indicating that the openness for inter-religious cooperation is the "flip side" of plurality.

Alana Sá Leitão Souza's reflections on the particular religious circumstances in the Brazilian city of Abreu e Lima put the dimensions back in perspective. The municipal area is famous for the outstanding demographic density of Pentecostals among the inhabitants and the close coexistence of a number of competing evangelical churches. The author argues that this situation is favorable for tensions not only between local religious institutions but also for internal conflicts of individuals who have to negotiate how to conceal their commitment to a certain church with the values of the modern society.

Antonio Genivaldo Cordeiro de Oliveira's article confronts the reader with a completely different geographical scenario. He deals with conflicts within the Catholic Church of Japan fueled by a growing number of Catholic Brazilian foreign workers, their often-charismatic religious orientation and the Pastoral work of institutions operating in the name of the immigrants.

Paulo Barrera Rivera's case study on prominent religious leaders in Peru switches back to intermittent collaboration as one of the possible side-effects of religious pluralism. The author describes the concerted action of three religious leaders of different spiritual backgrounds (Protestant, Pentecostal, and Catholic). Their union in the struggle against abortion indicates that shared political interest can lead to temporary collaboration beyond animosities and market logics.

Sandra Milena Rios Oyola approaches the spectrum of humanitarian activities developed by the Catholic Church in response to the increasing violence in one of Colombia's economically most underprivileged areas. The engagement of the Church for the rights of the most affected local ethnic groups is rooted in Liberation Theology and includes, alongside political and juridical measures, means of reawakening social memory present in shared religious narratives, symbols, and rituals.

The last two essays of the thematic section deal with Guatemala. Andrea Althoff is interested in how the emphasis on ethno-cultural distinctiveness, religious reorientation, and political activism of the Maya movement challenge the historical alliance between national and Catholic collective identity as well as of the more recent aspiration of Pentecostalism to replace the Catholic component of this conjunction.

C. James MacKenzie describes and analyses the significance, political implications, religious functions, and tensions between the participants of an itinerant event called "Sacred Circle of Wise Grandmothers and Grandfathers of the Planet" which in 2014 was organized in Guatemala by members of the Maya community.

In addition, the reader finds the articles of two authors in response to our invitation to submit at any time "original papers" on subjects within the wider scope of interest 
indicated by the title of our journal. Simone Fracas gives an overview of the State of Arts of the study of Gerónimo de Mendieta and introduces an alternative historical approach to this key figure among the early proselytizing members of the Franciscan order in New Spain. Eric Roth summarizes the results of his empirical psychological study on the relationship between empathy, antisocial behavior, religiosity, and spirituality among Bolivian university students.

An Interview with the Presidents of the Latin American Jewish Studies Association, a report on the First International Congress of the Chilean Society for the Sciences of Religions as well as the reviews of two relevant publications complete the second issue of the International Journal of Latin American Religions. 